\title{
IPTEKS PERLAKUAN AKUNTANSI KREDIT USAHA RAKYAT PADA PT. BANK MANDIRI (PERSERO) TBK. AREA MANADO
}

\author{
Maya Sembiring ${ }^{1}$, I Gede Suwetja ${ }^{2}$ \\ ${ }^{1,2}$ Jurusan Akuntansi, Fakultas Ekonomi dan Bisnis Universitas Sam Ratulangi, Jl. Kampus Unsrat, Manado, \\ 95115, Indonesia \\ E-mail: mayasembiring.ms@gmail.com
}

\begin{abstract}
PT. Bank Mandiri (Persero) Tbk. It is one of the agencies that implements the People's Business Credit (KUR) program in providing loans to parties Micro, Small and Medium Enterprises (UMKM) who want to open a business. Accounting treatment in the People's Business Credit (KUR) program is very important for creditors and prospective debtors because with Accounting both parties can plan business financial properly. The purpose of this study was to analyze the accounting treatment of people's business credit at PT. Bank Mandiri (Persero) Tbk. Manado area. Based on the results of the Accounting research applied by Bank Mandiri to Micro, Small and Medium Enterprises (UMKM) who want to open a business. Accounting treatment in the People's Business Credit (UMKM)is income statement. The Income statement is one of the conditions for prospective debtors so that credit disbursement can be disbursed because the income statement contains information about the income, expenses and net income received by the company in a period of one month. So that the results of the profits obtained by Bank Mandiri can see how much credit limit the company can give to prospective debtors. Bank Mandiri applies DSR as one of the conditions for calculating the approved limit. DSR is a ratio that calculates how much income is obtained by prospective debtors to pay the total debt.
\end{abstract}

Keywords : Kredit Usaha Rakyat (KUR), Usaha Mikro Kecil dan Menengah (UMKM), income statement, debt to service ratio (DSR)

\section{PENDAHULUAN}

Di era globalisasi yang semakin pesat ini persaingan untuk mendapatkan pekerjaan semakin ketat, karena selain jumlah penduduk yang semakin cepat bertambah, banyak perusahaan-perusahaan yang mencari pekerja dengan standar keterampilan yang baik seperti memiliki gelar sarjana dan mampu beradaptasi dengan cepat dalam menghadapi perkembangan zaman dimana keperluan agar dapat membiayai kebutuhan hidup semakin tinggi. Untuk itu agar dapat menyesuaikan dengan perkembangan zaman yang ada sebaiknya masyarakat berpikir mencari solusi lain dalam menambah penghasilan ataupun sebagai alternative penghasilan untuk memenuhi biaya kebutuhan sehari-hari yang semakin tinggi. Membuka bisnis atau usaha merupakan salah satu solusi yang bisa kita terapkan jika ingin memakmurkan Negara. Di Indonesia kita pasti banyak menemukan usaha-usaha kecil yang biasa disebut Usaha Mikro Kecil dan Menengah (UMKM), UMKM sudah terbukti tahan terhadap macam-macam goncangan krisis ekonomi di Indonesia. Berdasarkan UndangUndang Nomor 20 Tahun 2008 tentang Usaha Mikro, Kecil dan Menengah (UMKM) "Ada beberapa kriteria UMKM yang di berikan oleh pemerintah sebagai batasan jenis usaha yang didasarkan atas jumlah aktiva yang dimiliki". UMKM termasuk sebagai salah satu bisnis yang memiki peran penting dalam memberikan sumbangan ke Pemerintah.

Institusi Perbankan memandang positif perkembangan potensi UMKM di Indonesia sehingga Perbankan memberikan dukungan dengan memberikan penyaluran kredit kepada pelaku UMKM berada di Indonesia. PT. Bank Mandiri (Persero) Tbk merupakan salah satu 
instansi perbankan yang sudah menerapkan KUR sebagai salah satu solusi pemberian modal UMKM di Indonesia. (Kompas.com) "KUR PT.Bank Mandiri pada bulan Desember telah disalurkan sebesar Rp 11,83 Triliun kepada 179.294 debitur.

Akuntansi merupakan salah satu proses yang dapat mengoptimalkan perencanaan usaha lewat pencatatan dan pembukuan dan akan membetuk sebuah laporan keuangan dimana laporan keuangan tersebut dapat menggambarkan proses pengeluaran dan pemasukan dana yang dibutuhkan sehingga dapat dilihat perkembangan usaha tersebut sudah sampai sejauh mana, untuk itu akuntansi sangat diperlukan dalam membantu memanfaatkan KUR yang diberikan dalam mengembangkan usaha yang ada, karena dengan menerapkan Akuntansi dalam pengelolaan usaha dapat membangun kepercayaan bank dalam memberikan KUR terhadap pelaku UMKM sehingga pihak bank dapat melihat kedepan kelayakan dari proses usaha yang dijalankan dan dapat mengawasi perkembangan KUR yang telah dimanfaatkan oleh UMKM.

\section{TINJAUAN PUSTAKA}

Peran Akuntansi terhadap Kredit Usaha Rakyat. Kredit Usaha Rakyat adalah pemberian kredit dari perbankan kepada UMKM yang dianggap feasible tapi belum bankable. KUR bertujuan untuk mengembangkan UMKM yang ada di Indonesia dengan mendorong perekonomian Indonesia, dan membuka lapangan pekerjaan baru bagi masyarakat sekitar. (www.bankmandiri.com). Berdasarkan Peraturan Menteri Keuangan No. 135/PMK.05/2008 tentang fasilitas peminjaman kredit usaha rakyat yang diubah dengan Peraturan Menteri Keuangan No. 10/PMK.05/2009. Yang menjadi syarat pengajuan KUR yang telah ditetapkan oleh pemerintah adalah sebagai berikut :

1. Peminjaman yang dilakukan oleh pihak UMKM harus sesuai dengan ketentuan yang berlaku.

2. KUR yang akan disalurkan ke masyarakat harus sesuai dengan ketentuan yang berlaku.

3. Pihak bank harus menilai kelayakan usaha dari pihak UMKM sudah memiliki kinerja keuangan yang bagus sesuai dengan ketentetuan yang belaku.

Menurut Kieso (2007:2) Akuntansi Keuangan merupakan proses pencatatan, pengelompokkan, pelaporan dan pengevaluasi suatu transaksi keuangan yang berakhir pada laporan keuangan dan menjadi informasi bagi pihak internal maupun eksternal dalam pengambilan keputusan. Akuntansi membantu dalam penilaian kelayakan usaha yang dijalankan serta pihak bank dapat mengawasi perkembangan atas pemanfaatan KUR pada UMKM. Menurut Ikatan Akuntansi Indonesia (2016) Laporan Keuangan merupakan proses pencatatan akuntansi perusahaan dalam periode tertentu yang menjadi informasi kinerja peusahaan. Laporan keuangan digunakan oleh pihak internal maupun eksternal sebagai informasi keuangan dalam menganalisis kinerja keuangan perusahaan.

Penyusunan Laporan Laba Rugi berdasarkan SAK EMKM. (SAK EMKM, 2016) Standar Akuntansi Keuangan Entitas Mikro, Kecil dan Menegah merupakan standar akuntansi keuangan yang diterapkan Ikatan Akuntansi Indoensia (IAI) yang dirancang khusus bagi pelaku UMKM. Laporan laba rugi SAK EMKM terdiri dari pendapatan, beban keuangan serta beban pajak suatu entitas. Semua penghasilan dan beban usaha yang dijalankan dimasukkan dalam laporan laba rugi perusahaan namun yang dimasukkan harus diakui dalam satu periode, kecuali syarat lain ED SAK EMKM. Informasi kinerja laporan laba rugi menurut SAK EMKM sebagai berikut :

1. Pendapatan (revenue) adalah jumlah keuangan perusahaan yang diterima dari hasil penjualan produk (barang/jasa) ke pelanggan dan bukan berasal dari penanaman modal.

2. Penghasilan (income) adalah jumlah keuangan perusahaan yang telah dikurangi beban dan biaya perusahaan atau bisa disebut laba bersih. 
3. Beban (expense) adalah jumlah keuangan perusahaan yang dikeluarkan guna membiayai kebutuhan perusahaan.

Menurut Baridwan (2004), terdapat 2 jenis laporan laba rugi dalam menyusun laporan keuangan yaitu laporan laba rugi single step dan laporan laba rugi multistep. Laporan laba rugi single step merupakan laporan laba rugi yang berisi semua pendapatan dan beban termasuk pendapatan dan beban dari luar usaha, sehingga profit yang didapatkan dihitung dari selisih antara pendapatan dikurangi beban. Sedangkan, laporan laba rugi multi step merupakan laporan laba rugi yang memisahkan secara terperinci antara pendapatan dan beban dari luar usaha. Dalam laporan laba rugi SAK EMKM terdiri dari 3 akun keuangan yaitu pendapatan, beban keuangan, dan beban pajak. Jika ketiga akun ini dijumlahkan maka akan diperoleh laba bersih perusahaan.

Debt to Service Ratio. Debt to Service Ratio (DSR) merupakan ratio yang membuktikan seberapa besar jumlah pendapatan yang diperoleh setahun untuk membayar total utang tahunan (Eka Budianti, 2010). Dalam perbankan DSR merupakan standar dalam pengambilan keputusan untuk jumlah limit kredit yang akan disetujui oleh pihak bank terhadap pendapatan calon debitur. DSR menjadi patokan bagi pihak bank dalam memberikan kredit kepada calon debitur agar tidak terjadi kredit macet saat menjalankan angsuran kredit. Nilai DSR yang diajukan setiap perusahaan berbeda-beda sekitar 30\%-40\%.

Perhitungan Debt to Service Ratio (DSR) yang digunakan Bank Mandiri yaitu :

DSR = Laba Bersih x 35\%

Menurut Amiza (2016), Debt to Service Ratio merupakan indikator yang paling berpengaruh dalam pengukuran beban utang yang harus dibayar pihak yang meminjam kepada pihak yang memberi pinjaman. DSR sangat berpengaruh terhadap pencairan kredit calon debitur sehingga pihak kreditur menrapkan DSR dalam Nota Analisis Kredit (NAK) sebagai batas limit kredit yang akan dicairkan oleh pihak kreditur.

\section{METODE DAN TEKNIK PENERAPAN IPTEKS}

\subsection{Metode Penerapan Ipteks}

Metode Ipteks yang diterapkan adalah mengaplikasikan penyusunan laporan keuangan Usaha Kecil Menengah (UKM) sesuai dengan Standar Akuntansi Keuangan Entitas Mikro Kecil Menengah (SAK EMKM) yang berlaku sebagai syarat pemberian kredit usaha rakyat PT. Bank Mandiri (Persero) Tbk. Area Manado agar tidak terjadi kredit macet.

\subsection{Teknik Penerapan Ipteks}

Teknik penerapan ipteks yang digunakan adalah setelah mengamati proses pemberian kredit yang dilakukan oleh pihak PT. Bank Mandiri (Persero) Tbk. Area Manado kepada UMKM agar tidak terjadinya kredit macet, maka perlu dilakukan penyusunan laporan keuangan menurut Standar Akuntansi Keuangan Entitas Mikro Kecil. Laporan Keuangan yang diterapkan pihak PT. Bank Mandiri (Persero) Tbk. Area Manado yakni penyusunan laporan laba rugi perusahaan. Terdapat 2 jenis laporan laba rugi menurut Baridwan (2004), laporan laba rugi yang cocok untuk penyusunan laporan laba rugi UMKM ialah laporan laba rugi single step karena laporan laba rugi single step lebih simpel sehingga tidak membingungkan pihak yang ingin menggunakannya

\section{PEMBAHASAN}

\subsection{Gambaran Objek Penerapan Ipteks}

PT. Bank Mandiri (Persero) Tbk didirikan pada tanggal 2 Oktober 1998 dan merupakan bagian dari program restrukturasi perbankan yang dilaksanakan oleh pemerintah Indonesia. Bank Mandiri termasuk bank terbesar di Indonesia yang memproses tentang aset, pinjaman dan deposito. Bank Mandiri memiliki tujuan untuk mengapresiasi para pengusahapengusaha muda dalam meningkatkan UMKM berkualitas di Indonesia sehingga bank 
mandiri mendukung proses pemberian Kredit Usaha Rakyat pada Masyarakat.

\subsection{Pembahasan}

Saat mengajukan kredit pihak bank harus menilai permohonan kredit yang diajukan oleh calon debitur sudah terstruktur dengan baik dan tidak mengakibatkan kredit macet, untuk itu perlu dilakukan analisis kredit. Dalam menganalisis kredit perlu kita terapkan akuntansi agar proses analisis dapat terkontrol dengan baik. Perlakuan Akuntansi yang di bahas pada penelitian ini ialah perhitungan penyususnan laporan keuangan laba rugi perusahaan, laporan laba rugi merupakan syarat acuan pencairan kredit di PT. Bank Mandiri (Persero) Tbk. Area Manado. Laporan laba rugi yang diguanakan dalam SAK EMKM ialah laporan laba rugi single step yang terdiri dari tiga akun keuangan yaitu pendapatan, beban keuangan dan laba, Laba bersih akan diperoleh jika ketiga akun tersebut telah di jumlahkan. Berikut penulis lampirkan contoh laporan laba rugi calon debitur yang akan dihitung batas kemampuan bayar kredit, sebagai berikut :

Tabel 1. Laporan Laba Rugi Agustus 2018 Toko "ABC"

\begin{tabular}{lcc}
\hline & Uraian & Waktu \\
\cline { 2 - 4 } & \multicolumn{3}{c}{ Agustus 2018 } \\
\hline Pendapatan & Rp & 13.656 .250 \\
Beban Keuangan & & \\
Gaji Pegawai & $\mathrm{Rp}$ & 1.500 .000 \\
Transportasi & $\mathrm{Rp}$ & 400.000 \\
Listrik & $\mathrm{Rp}$ & 300.000 \\
Cadangan Kas Operasional & $\mathrm{Rp}$ & 300.000 \\
Jumlah Beban Keuangan & $\mathrm{Rp}$ & 2.500 .000 \\
LABA SEBELUM PAJAK & $\mathrm{Rp}$ & 11.156 .250 \\
\hline
\end{tabular}

Sumber : Data Mikro Banking Cluster Manado 2018

Dari ilustrasi tabel di atas penulis mendapatkan data pendapatan sebesar Rp 13.656.250,- Beban Keuangan sebesar Rp 2.500.000,- dan Laba sebesar Rp 11.156.250,selama bulan agustus 2018. Dengan dibuatnya laporan laba rugi tersebut pihak bank dapat melihat kemapuan bayar dari calon debitur dalam melunasi peminjaman modal kerja yang diberikan oleh pihak bank melalui pengukuran Debt Service Ratio (DSR). Pihak bank Bank Mandiri menerapkan DSR sebesar 35\% untuk angsuran kredit yang harus dibayarkan oleh calon debitur sehingga jumlah limit peminjaman yang disetujui oleh pihak bank dapat dihitung sebagai berikut :

$$
\begin{array}{ll}
\text { Limit yang diajukan } & =\operatorname{Rp} 150.000 .000 / 36 \mathrm{bulan} / 0.57 \% \\
\text { Jumlah Limit yg disetujui } & =\operatorname{Rp} 11.156 .250 \times 35 \%=\operatorname{Rp} 3.904 .687,- \text { per bulan } \\
& =\operatorname{Rp} 3.904 .687,- \text { x } 36 \text { bulan = Rp 140.568.732,- } \\
\text { Selisih } & =\operatorname{Rp~9.431.268,-~}
\end{array}
$$

Limit yang diajukan tidak sesuai dengan limit yang disetujui sehingga terdapat selisih sebesar Rp 9.431.268,-. Untuk itu limit pembayaran yang disetujui oleh kreditur sebesar Rp 140.000.000,- (dibulatkan) dengan pembayaran angsuran per bulan Rp 3.911.000,- jangka waktu 3 tahun (36 bulan) bunga $0.57 \%$.

Limit $\quad=\operatorname{Rp~} 140.000 .000 / 36$ bulan $=\operatorname{Rp} 3.888 .889,-$

$$
=\operatorname{Rp} 3.888 .889 \times 0.57 \%=\text { Rp. 22.167.- }
$$

Angusran $\quad=\operatorname{Rp} 3.888 .889+\operatorname{Rp} 22.176=\operatorname{Rp} 3.911 .000,-($ dibulatkan $)$ 
Perhitungan diatas menggambarkan batas kemampuan pembayaran angsuran kredit calon debitur selama 1 bulan. Dari limit yang diinginkan calon debitur sebesaar Rp 150.000.000 angsuran selama 3 tahun (36 bulan) dengan bunga 0,57\% tidak disetujui oleh pihak kreditur karena DSR dari calon debitur dinilai tidak memenuhi syarat DSR bank mandiri. Untuk itu pihak bank menyetujui limit kredit untuk calon debitur hanya sebesar Rp 140.000.000,-. Karena di limit Rp 140.000.000,-- pihak debitur mampu membayar cicilan angusuran yang diterapkan oleh pihak bank mandiri dan terjadinyan kredit macet akan semakin kecil. Dari data diatas dengan menerapkan akuntansi dalam bidang UMKM maka sangat membantu pihak bank untuk mengontrol keuangan usaha serta mampu menilai kelancaran pembayaran angsuran yang akan dijalankan oleh pihak kreditur.

\section{KESIMPULAN DAN SARAN}

\subsection{Kesimpulan}

PT. Bank Mandiri (Persero) Tbk. Merupakan instansi perbankan yang memiliki program KUR sebagai salah satu alternative pemberian kredit kepada pihak UMKM yang dianggap feasible tapi belum bankable, maksdnya ialah pemeberian kredit dapat digunakan oleh seluruh kalangan masyarakat khususnya pengusaha muda yang memiliki prospek usaha yang bagus. Dengan diterapkannya KUR pihak krediur lebih teliti dalam pemeriksaan laporan keuangan pihak UMKM karena sangat berpengaruh dalam kelancaan perusahaan dalam mengambil keputusan untuk keluar masuknya kas, Laporan laba rugi merupakan salah satu terapan akuntansi yang paling penting dalam menilai kelancaran suatu usaha seningga laporan laba rugi yang diterapkan menjadi salah satu syarat oleh pihak bank mandiri dalam hal ini laporan laba rugi single step dapat membantu menilai kelancaran usaha yang dijalankan pihak UMKM dan menjadi informasi penting bagi pihak bank dalam mengambil keputusan

\subsection{Saran}

Dalam perhitungan laporan laba rugi yang diterapkan sebaiknya perusahaan menerapkan beban pajak dalam laporan keuangan agar dapat diperoleh nilai laba bersih yang sesungguhnya dalam menghitung kemampuan bayar calon debitur. Karena pajak merupakan bagian yang sangat penting bagi pemerintah untuk meningkatkan pendapatan negara.

\section{DAFTAR PUSTAKA}

Ningtyas Jilma. 2017. Penyusunan Laporan Keuangan UMKM Berdasarakan Standar Akuntansi Keuangan Entitas Mikro Kecil dan Menengah (SAK EMKM).Riset \& Jurnal Akuntansi. 2(1)

IAI 2016. Standar Akuntansi Keuangan Entitas Mikro, Kecil dan Menengah. Jakarta: Dewan Standar Akuntansi Keuangan

Ikatan Akuntan Indonesia (IAI). 2012. Standar Akuntansi Keuangan. Jakarta: Salemba Empa

Rachmat Vicky, Retnadi H., Kurniawati Rina. 2014. Perancangan Aplikasi Laporan Laba

Rugi Menggunakan Metode Berorientasi Objek. Jurnal Algoritma. 11(1)

Baridwan, Zaki. 2004. Intermediate Accounting. Yogyakarta: BPFE-YOGYAKARTA

Purnama Nur, Ruliana Tiin, Suyatin. 2015. Penerapan Akuntansi Sumber Daya Manusia Dan Kinerja Keuangan Pada PT. Bank Mandiri

Soviana Rurun. 2013. Mekanisme dan Strategi Penyaluran Kredit Usaha Rakyat (KUR) Mikro. Jurnal Akuntansi

Peraturan Menteri Keuangan No. 10/PMK.05/2009. Fasilitas Peminjaman Kredit Usaha Rakyat. Jakarta

Budianti, Eka, dkk. 2010. Analisis Faktor Fundamental Ekonomi yang Mempengaruhi Risiko Pinjaman Luar Negeri Indonesia. Jurnal Ekonomi dan Kebijakan Pubik, 1(1) 
Wilanda Amiza. 2016. Analisis Faktor Yang Mempengaruhi Debt To Service Ratio di Indoensia. Skripsi. Lampung. Universitas Lampung.

Atmanto Dwi, Handayani Siti, Mahardhika Sandra. 2014. Sisitem Akuntansi Pengajuan dan Pelunasan Angsuran Kredit Usaha Rakyat Dalam Mencapai Tujuan Pengendalian Intern. Jurnal Administrasi Bisnis. 14(2)

PT. Bank Mandiri (Persero) Tbk. 2018. Kredit Usaha Rakyat di https://www.bankmandiri.co.id (diakses 25 Oktober) 